\title{
Personal Branding Valentino Simanjuntak sebagai Komentator Olahraga di Media Televisi
}

\author{
Naufal Ferdiansyah ${ }^{1}$, Amalia Djuwita ${ }^{1}$ \\ ${ }^{1}$ Program Studi Ilmu Komunikasi, Fakultas Komunikasi dan Bisnis, Universitas Telkom, \\ Jl Telekomunikasi Terusan Buah Batu, Bandung 40257
}

Penulis untuk Korespondensi/E-mail: naufalferdiansyah7@gmail.com

\begin{abstract}
Abstrak - Penelitian ini merupakan penelitian kualitatif mengenai "Personal Branding Valentino Simanjuntak sebagai Komentator Olahraga di Media Televisi”. Tujuan dari penelitian ini adalah menganalisis bagaimana penerapan personal branding yang dilakukan oleh Valentino Simanjuntak sebagai komentator olahraga di media televisi. Penelitian ini menggunakan metode kualitatif dengan jenis penelitian analisis deskriptif. Paradigma yang digunakan dalam penelitian ini ialah post-positivisme karena peneliti ingin membuktikan dan menganalisa suatu fenomena yang terjadi pada subjek penelitian dengan berpedoman teori yang sudah ada dan berpaku pada suatu teori. Dalam objek penelitian penulis memilih Valentino Simanjuntak sebagai informan kunci, lalu memilih Ary Sapari dan Petrus Tomy Wijanarko sebagai informan pendukung dan memilih Dra. Dewi Taviana Walida, Psi, Psikolog sebagai informan ahli. Berdasarkan hasil penelitian menunjukkan bahwa dalam melakukan personal branding, Valentino Simanjuntak hadir sebagai komentator olahraga di media televisi yang memiliki ciri khas variasi ragam bahasanya saat menjadi komentator olahraga yaitu slang, jargon, akrolek, dan ken dengan sebelas karaktersitik personal branding yaitu keaslian, integritas, konsisten, spesialisasi, wibawa, kekhasan, relevan, terlihat, kegigihan, nama baik, dan kinerja yang sudah cukup baik dan selaras. Akan tetapi, pada poin kewibawaan, untuk diakui sebagai ahli dalam bidang komentator olahraga Valentino Simanjuntak masih membutuhkan waktu dan proses lagi untuk memenuhi kriteria kewibawaan.
\end{abstract}

Abstract - This research is a qualitative research on "Personal Branding Valentino Simanjuntak as Sports Commentator on Television Media". The purpose of this research is to analyze the way of applying personal branding carried out by Valentino Simanjuntak as a sports commentator on television media. This study uses qualitative methods with a type of descriptive analysis research. The paradigm used in this research is post-positivism because researchers want to prove and analyze the phenomena that occur in the subject of research by referring to existing theories and sticking to a theory. In the research object, the author choose Valentino Simanjuntak as the key informant, then choose Ary Sapari and Petrus Tomy Wijanarko as supporting informants and chose Dra. Dewi Taviana Walida, Psi, Psychologist as expert informant. The result of this research shows that in conducting personal branding, Valentino Simanjuntak was present as a sports commentator on television media who has a uniqueness of language variation like slang, jargon, akrolek, and ken with eleven personal branding characteristics namely authenticity, integrity, consistency, specialization, authority, distinctiveness, relevant, visibility, persistence, goodwill, and performance. It is good enough and in harmony. However, in terms of authority, to be recognized as an expert in the field of sports commentator Valentino Simanjuntak still needs more time and process to fulfill the criteria of authority

Keywords - Language Variety, Personal Branding, Sports Commentator 


\section{PENDAHULUAN}

$\mathrm{B}$ erawal dari hanya membantu mengisi acara di televisi, Valentino Simanjuntak bisa menjadi komentator yang sangat dikenal masyarakat dengan ciri khasnya dengan gaya berbicara cepat, nyentrik, dan melontarkan jargon- jargon unik yang membuat penonton antusias dan bersemangat. Pada akhirnya Valentino Simanjuntak yang lebih dikenal sebagai Valentino Jebreeet menjadi salah satu orang yang sangat dikenal masyarakat Indonesia terutama pecinta olahraga.

Valentino Simanjuntak mulai berkembang karirnya sebagai komentator olahraga saat ditawarkan untuk mengomentatori acara sepakbola piala AFF U-19 tahun 2013, saat itu ia diminta untuk membuat gaya berkomentator yang berbeda, karena pada saat itu yang bermain tim nasional sepakbola U-19 tidak banyak yang mengetahui, maka dari itu dia diminta untuk membuat perbedaan, pada saat itu akhirnya seorang Valentino Simanjuntak membangun positioning nya sebagai komentator olahraga yang nyentrik, out of the box, dan berbeda [1]. Pada tahun 2013 Valentino Simanjuntak menggemparkan dunia pertelevisian Indonesia dengan cara dia membawakan komentar terhadap pertandingan pertandingan sepakbola piala AFF U-19 tahun 2013. Dengan gaya berkomentatornya yang ramai, cepat, dan nyentrik membuat Valentino Simanjuntak viral di pertelevisian Indonesia dan menjadi perbincangan netizen di media sosial. Salah satu kalimat yang paling viral adalah saat dimana Valentino Simanjuntak mengatakan kata "jebreeet" saat timnas Indonesia memasukan bola ke gawang lawan. Kata- kata "jebreeet" saat itu langsung viral dan dibicarakan netizen di media sosial. Tidak hanya dibicarakan saja, melainkan di share cuplikannya di media sosial sampai dibuat kompilasi saat dia mengatakan "jebreeet" saat berkomentator di platform Youtube [2].

Secara tidak langsung personal branding dari Valentino Simanjuntak sudah terlihat dari gaya berkomentatornya yang beda dan unik, dan nyentrik. Seperti kita tahu bahwa komentator olahraga khususnya sepakbola biasanya dibawakan secara formal, tetapi dengan kehadiran Valentino Simanjuntak di acara televisi menjadi perbedaan dengan cara membawakan komentar yang ramai, gaya bahasa cepat, dan mengeluarkan kata - kata dan jargon unik, dan nyentrik.

Piala AFF U-19 2013 hanyalah awal dari perjalanan Valentino Simanjuntak dengan ciri khas pembawaan nyentriknya dan jargon uniknya. Setelah sukses Menemukan ciri khas pada dirinya, Valentino Simanjuntak terus mengeluarkan ide - ide baru saat ia menjadi komentator di acara olahraga. Jargon jargon unik dan kata - kata yang membuat penonton bertanya - tanya sukses membuat Valentino Simanjuntak semakin mengudara. Berawal dari kata - kata "jebreeet" pada Piala AFF U-19 pada tahun 2013, berlanjut dengan jargon - jargon seperti "tendangan LDR", "gerakan 378", sampai membuat julukan untuk pemain timnas U-19 pada Piala AFF U-19 pada tahun 2017 seperti "messi kelok 9", "Benteng Rotterdam", "baby shark" dan banyak lagi.

Dari tahun ke tahun Valentino Simanjuntak selalu memberikan ide-ide baru yang mengarah dari personal branding nya sebagai komentator olahraga yang berbeda dan unik. Valentino Simanjuntak menjadi seorang komentator sepakbola dengan gayanya yang berbeda, nyentrik, dan unik, jargon jargon unik yang ia buat berhasil membuat dirinya menjadi viral di pertelevisian Indonesia, nama Valentino Jebreeet sebagai julukannya pun sudah melekat di mata masyarakat sehingga terbentuklah personal branding nya. Sampai akhirnya ia mendapatkan penghargaan sebagai presenter olahraga terfavorit di Panasonic Gobel Award 2018. Valentino Simanjuntak mampu mengalahkan beberapa presenter - presenter olahraga di Indonesia seperti Darius Sinathrya dan Donna Agnesia [3].

Dengan demikian, penulis tergerak untuk melakukan penelitian yang berjudul "Personal Branding Valentino Simanjuntak Sebagai Komentator Olahraga di Media Televisi" karena Valentino Simanjuntak merupakan tokoh yang viral dengan gaya berkomentatornya yang berbeda, unik, dan nyentrik. Perjalanannya dari awal menjadi komentator, viral dengan ciri khasnya, hingga akhirnya pencapaiannya terbayar dengan terpilihnya dia menjadi presenter olahraga terfavorit di Panasonic Gobel Award 2018 memperkuat bahwa seorang Valentino Simanjuntak memiliki mereknya sendiri dan sukses membangun personal branding.

\section{METODE}

Penelitian pada hakikatnya merupakan suatu cara atau upaya untuk menemukan suatu kebenaran atau memperbaiki kebenaran menjadi lebih benar lagi. Metode penelitian pada dasarnya merupakan cara ilmiah untuk mendapatkan data dengan tujuan dan kegunaan tertentu [4]. Penelitian ini dilakukan pada 
bulan Oktober 2018 sampai dengan bulan April 2019. Penelitian ini menggunakan metode penelitian analisis deskriptif kualitatif. Penelitian kualitatif merupakan penelitian yang bermaksud untuk memahami fenomena tentang apa yang dialami oleh subjek penelitian [5]. Subjek pada penelitian ini adalah Komentator Olahraga Valentino Simanjuntak. Tujuan penelitian ini adalah untuk memahami suatu fenomena yang kadang sulit untuk diketahui dan sulit untuk dipahami.

Menurut [6], penelitian deskriptif ditujukan untuk: (1) mengumpulkan informasi aktual secara rinci yang melukiskan gejala yang ada, (2) mengidentifikasi masalah atau memeriksa kondisi dan praktek-praktek yang berlaku, (3) membuat perbandingan atau evaluasi, (4) menentukan apa yang dilakukan orang lain dalam menghadapi masalah yang sama dan belajar dari pengalaman mereka untuk menetapkan rencana dan keputusan pada waktu yang akan datang. Teknik pengumpulan data menggunakan data primer yaitu wawancara, wawancara langsung dilakukan secara semi-struktur agar wawancara bisa lebih mendalam. Data sekunder membantu kelengkapan penelitian melalui observasi, dokumentasi, referensi buku dan sumber - sumber lainnya. Hingga akhirnya data - data penelitian yang didapat harus di uji keabsahannya. Menurut [7], keabsahan data adalah bagian yang penting dalam suatu penelitian dimana untuk menguji setiap data penelitian yang dilakukan dalam memenuhi kriteria kebenaran.

Penelitian ini menggunakan paradigma postpositivisme karena peneliti ingin membuktikan dan menganalisa suatu fenomena yang terjadi pada subjek penelitian dengan berpedoman teori yang sudah ada dan berpaku pada suatu teori.

\section{HASIL DAN PEMBAHASAN}

Peneliti akan menguraikan hasil analisis personal branding Valentino Simanjuntak sebagai komentator olahraga di media televisi. Analisa akan dilakukan berdasarkan 11 kriteria Authentic Personal Branding yang Efektif oleh Rampersad (2008) dan ragam bahasa menurut Bachman (1990).

Personal Branding adalah proses di mana manusia dipandang dan dinilai sebagai sebuah brand oleh target market. Personal branding juga merupakan seni menarik lebih banyak klien dengan secara aktif membentuk persepsi publik. Dikatakan manusia dapat mengendalikan cara bagaimana manusia itu sendiri dipersepsikan oleh target market [8]. Menurut [9] mengatakan bahwa personal branding adalah identitas pribadi yang mampu menciptakan sebuah respon emosional terhadap orang lain mengenai kualitas dan nilai yang dimiliki orang tersebut.

\section{A. Keaslian (Authenticity)}

Nilai yang dibentuk oleh Valentino Simanjuntak dalam menjadi komentator olahraga adalah sebagai komentator olahraga yang memiliki ciri khas sendiri dan tentunya tidak mengikuti yang sudah ada, menggali kemampuan dan keunikan yang ada pada diri sendiri sehingga bisa dijadikan perbedaan dengan komentator olahraga lainnya.

Valentino Simanjuntak membentuk karakter personal branding nya sebagai komentator yang memiliki ciri khas dengan kata - kata "Jebreeet!" nya dan kata-kata lainnya serta dengan gaya berkomentator yang cepat dan ramai. Hal ini sesuai dengan apa yang dia lakukan saat menjadi komentator olahraga di media televisi dan selaras dengan ambisinya untuk menjadi komentator yang berbeda dan unik. Penulis menyimpulkan bahwa Valentino Simanjuntak telah memenuhi poin - poin dari karakteristik personal branding dalam hal keaslian (Authencity) dan poin - poin tersebut sudah selaras dengan ambisi pribadinya.

\section{B. Integritas (Integrity)}

Moral dan perilaku yang diterapkan Valentino Simanjuntak sebagai komentator olahraga di media televisi yaitu dalam hal originalitas, ia mengungkapkan bahwa mencari keunikan dan kemampuan sendiri akan lebih baik daripada mengikuti seseorang yang kita tahu bahwa kita tidak akan mencapai titik seperti mereka, perbedaan akan menjadi kekuatan tersendiri. Ia telah melakukan tata perilaku dan moral secara baik dengan tidak menjiplak hak seseorang dan tidak berkata - kata yang tidak seharusnya keluar saat menjadi komentator olahraga.

\section{Konsisten (Consistency)}

Valentino Simanjuntak sudah sangat konsisten dalam personal brandingnya sebagai komentator olahraga terlihat dari kata - kata "Jebreeet!" nya yang terus keluar dan menjadi ciri khasnya serta jargon - jargon unik lainnya seperti kutipan kutipan pahlawan, bahasa daerah, mengambil yang terkenal dari kedaerahannya, memberikan julukan 
pemain hal - hal tersebut dilakukan secara terus menerus dengan tetap fokus pada positioning nya sebagai komentator olahraga yang nyentrik, berbeda, dan out of the box di media televisi.

\section{Spesialisasi (Specialization)}

Dalam personal branding yang dilakukan Valentino Simanjuntak, dia mengeluarkan kemampuannya sebagai komentator olahraga yang memiliki spesialisasi dengan gaya berkomentator cepat, akrobat kata, dan kreativitas dalam membuat jargon - jargon unik. Selaras dengan karakteristik personal branding dalam hal spesialisasi yaitu dengan gaya berkomentator yang cepat, akrobat kata, kreativitas dalam membuat jargon - jargon unik, dan kekinian serta fokus pada satu bidang yaitu komentator olahraga di media televisi.

\section{E. Wibawa (Authority)}

Valentino Simanjuntak sudah di akui sebagai salah satu komentator olahraga terbaik dari masyarakat. Selaras dengan pernyataan Valentino Simanjuntak, wibawa dari Valentino Simanjuntak ada karena dia telah lama menekuni dunia komentator olahraga di Indonesia dan memiliki kedekatan dengan pemain bola yang berarti dia sudah diakui. Valentino Simanjuntak sudah berada di titik wibawa tapi belum maksimal, masih butuh proses dan waktu untuk bisa dikatakan sebagai seorang ahli di bidang komentator olahraga.

\section{F. Kekhasan (Distinctiveness)}

Valentino Simanjuntak sendiri adalah menjadi komentator olahraga di media televisi dengan gaya berkomentator cepat, ramai, dan akrobat kata. Valentino Simanjuntak menjelaskan dia memang tidak mau mengikuti orang lain yang mungkin tidak akan bisa seperti orang itu, lebih baik mengembangkan kemampuan dan mencari ciri khas sendiri. Valentino Simanjuntak memiliki kekhasan tersendiri yang membedakan dirinya sama komentator olahraga lainnya yaitu menjadi komentator olahraga yang berbeda dan unik di media televisi.

\section{G. Relevan (Relevant)}

Relevansi penonton televisi dengan personal branding yang ia lakukan sudah sesuai, karena saat ini penonton televisi di Indonesia lebih memilih tayangan yang menarik dan ada hiburannya, pada zaman dulu gaya berkomentator yang elegan dan casual yang diterima, tetapi di era milenial sekarang ini gaya berkomentator yang nyeleneh tapi mengundang hiburan lebih diterima.

\section{H. Terlihat (Visibility)}

Valentino Simanjuntak sudah masuk dalam kriteria ini karena dia adalah public figure di televisi Indonesia. Valentino Simanjuntak sudah memiliki komitmen dengan salah satu stasiun televisi di Indonesia jadi ia menjadi komentator olahraga di Piala Presiden, Liga 1, Piala AFF U-16, dan Asian Games 2018 kemarin.Valentino Simanjuntak dalam hal terlihat (Visibility) sudah sesuai dimana personal branding dari Valentino Simanjuntak disiarkan terus menerus, konsisten, dan tertanam dibenak audiens.

\section{Kegigihan (Persistence)}

Untuk tetap bertahan dalam membangun personal brandingnya, Valentino Simanjuntak tidak berhenti dengan satu karya saja, melainkan banyak karya yang ia buat untuk tetap bertahan. Selain jargon "Jebreeet!", Valentino Simanjuntak selalu mengeluarkan jargon - jargon unik baru setiap ia menjadi komentator olahraga di tiap acara olahraga seperti "Siapa kita? Indonesia!" di Asian Games 2018 kemarin, kutipan - kutipan pahlawan, bahasa daerah, mengambil sesuatu yang terkenal di suatu daerah, dan memberikan julukan pemain sampai akhirnya ada istilah - istilah terminologi khasnya Jebreeet di Jebreeetpedia. Valentino Simanjuntak dalam hal kegigihan dirasa sudah sesuai dengan fokus pada satu bidang yaitu komentator olahraga, tidak mudah menyerah, dan kreatif dalam membuat inovasi untuk personal branding nya.

\section{J. Nama Baik (Goodwill)}

Peneliti berpendapat bahwa Valentino Simanjuntak sudah baik dalam melakukannya, dikuatkan dengan pernyataan Valentino Simanjuntak suatu keharusan menjalin hubungan yang baik dengan pihak televisi dengan cara menjadi diri sendiri dengan originalitas diri sendiri karena menjalin hubungan dengan pihak televisi bisa jadi prospek jangka panjang. Menjalin hubungan baik dengan audiens dan fans juga penting bagi Valentino Simanjuntak karena tanggapan dari mereka juga bisa menjadi referensi, bagaimanapun juga seorang figur publik harus memberikan manfaat bagi audiens.

Valentino Simanjuntak sudah dikenal sebagai sosok yang positif, apalagi dengan jargon - jargonnya terutama "Siapa kita? Indonesia!" yang dipakai di 
Asian Games 2018 istilahnya bisa membangun semangat untuk Indonesia lebih maju lagi dan berprestasi, memiliki kebanggan saat menyebut jargon tersebut. Jadi Petrus Tomy menilai Valentino Simanjuntak sosok positif dengan membangun penonton atau atlet olahraga Indonesia untuk lebih maju lagi. Valentino Simanjuntak telah berhasil menjalin hubungan baik dan personal brand nya memberikan dampaak positif dan bermanfaat bagi khalayak.

\section{K. Kinerja (Performance)}

Kinerja yang dilakukan oleh Valentino Simanjuntak sudah baik dan sesuai berdasarkan personal branding Rampersad (2008) dalam hal kinerja. Valentino Simanjuntak menambahkan bahwa dalam menjaga eksistensinya, ia selalu berkomunikasi dengan pendukung, dengan pihak televisi, dan terus menciptakan ide - ide baru dalam membawakan acara olahraga, tentunya tolak ukurnya dari evaluasi di setiap waktu. Valentino Simanjuntak juga ingin merealisasikan untuk membuat buku tentang dirinya agar karya - karyanya dan perjalanannya bisa di nikmati oleh generasi - generasi berikutnya. Valentino Simanjuntak melakukan kinerjanya dengan baik dengan terus berevaluasi dan kreatif untuk membuat ide - ide dan inovasi baru terhadap personal brand nya di media televisi.

Bahasa adalah suatu sistem lambang berupa bunyi, bersifat arbiter, digunakan oleh suatu masyarakat tutur untuk bekerja sama, berkomunikasi, dan mengidentifikasi diri. Sebagai sebuah sistem, maka bahasa terbentuk oleh suatu aturan, kaidah, atau pola-pola tertentu, baik dalam bidang tata bunyi, tata bentuk kata, maupun tata kalimat [10]. Valentino Simanjuntak memiliki ciri khasnya tersendiri dengan jargon - jargon uniknya seperti tendangan LDR, umpan membelah lautan, julukan - julukan untuk pemain, kata - kata jebreeet nya yang membuat ia dikenal sebagai Valentino Jebreeet dan dia berhasil membangun personal brandingnya. Ragam bahasa adalah variasi bahasa menurut pemakaian, yang berbeda-beda menurut topik yang dibicarakan, menurut hubungan pembicara, kawan bicara, orang yang dibicarakan, serta medium pembicara [11]. Berkaitan dengan variasi bahasa berdasarkan tingkat golongan, status, dan kelas sosial para penuturnya dikenal adanya variasi bahasa akrolek, basilek, vulgar, slang, kolokial, jargon, argot, ken, dan prokem [12]. Dalam penelitian ini ada beberapa ragam bahasa yang digunakan Valentino Simanjuntak untuk personal brandingnya sebagai komentator olahraga yaitu:
A. Slang

Saat menjadi komentator olahraga, Valentino Simanjuntak menggunakan beberapa bahasa yang masuk dalam kategori slang seperti tendangan LDR, Gerakan 378, peluang 24 karat.

\section{B. Jargon}

Valentino Simanjuntak tentunya memiliki jargon utamanya yaitu "jebreeet!" dan jargon "siapa kita? Indonesia!" yang viral sampai diucapkan oleh bapak presiden jokowi saat penutupan Asian Games 2018. Jargon - jargon tersebut juga yang membuat nama Valentino Simanjuntak terus menanjak dan semakin dikenal orang hingga akhirnya menjadi presenter olahraga terfavorit di Panasonic Gobel Award 2018.

\section{Akrolek}

Valentino Simanjuntak terus membuat keunikan - keunikan baru yang membuat audiens terus penasaran dengannya, Valentino Simanjuntak membuat beberapa julukan untuk pemain Indonesia seperti Eggy messi kelok 9, Asnawi benteng Rotterdam, Rafli sang santri, dan Witan Baby Shark, julukan - julukan tersebut bukan tanpa makna, misal Eggy Messi kelok 9 karena Eggy seperti Lionel Messi nya Indonesia dan ia berasal dari Padang, dan Rafli sang santri yang memperlihatkan bahwa background Rafli dulunya adalah seorang santri.

\section{Ken}

Dengan gayanya yang ramai, nyentrik, dan bergaya ngomong cepat, Valentino Simanjuntak melontarkan kata - kata seperti umpan kepepet, keretakan rumah tangga pertahanan, mantan terundang, dan sang prahara penghancur keharmonisan rumah tangga.

\section{KESIMPULAN}

Dalam melakukan personal branding, Valentino Simanjuntak hadir sebagai komentator olahraga di media televisi yang memiliki ciri khas variasi ragam bahasanya saat menjadi komentator olahraga yaitu slang, jargon, akrolek, dan ken dengan sebelas karaktersitik personal branding menurut Rampersad (2008) yaitu keaslian, integritas, konsisten, spesialisasi, wibawa, kekhasan, relevan, terlihat, kegigihan, nama baik, dan kinerja yang sudah cukup baik dan selaras. Akan tetapi, pada poin kewibawaan, untuk diakui sebagai ahli dalam bidang komentator olahraga Valentino Simanjuntak masih membutuhkan waktu dan proses lagi untuk 
memenuhi kriteria kewibawaan, karena diakuinya seseorang dibidang tertentu membutuhkan waktu dan proses. Hanya dengan viral dan terkenal saja belum cukup untuk memenuhi kriteria kewibawan, jika terus fokus dibidangnya, bukan tidak mungkin Valentino Simanjuntak bisa memenuhi kriteria personal branding dalam hal kewibawaan.

Dalam penelitian ini terdapat dua saran, yaitu saran akademis dan saran praktis. Berikut penjabarannya:

\section{Saran Akademis}

1. Penelitian selanjutnya diharapkan melakukan penelitian dengan menggunakan objek yang sama dengan subjek maupun platform yang berbeda agar bisa lebih mendalami dan menggali penelitian tentang personal branding

2. Penelitian selanjutnya diharapkan melakukan penelitian dengan menggunakan subjek yang sama dengan objek maupun teori yang berbeda untuk mendapatkan hasil penelitian baru.

\section{Saran Praktis}

1. Konsisten dan munculkan inovasi - inovasi baru pada personal brand yang dimiliki dan dilakukan oleh informan kunci agar personal branding bisa lebih baik dan semakin melekat di khalayak luas.

2. Menguatkan personal branding dalam hal kewibawaan, agar personal branding yang dilakukan oleh informan kunci menjadi lebih baik dan pada akhirnya diakui sebagai orang yang ahli dibidang tertentu yaitu bidang komentator olahraga dan menjadi komentator olahraga yang berpengalaman seiring berjalannya waktu.

\section{REFERENSI}

[1]. N. Ferdiansyah, "Personal Branding Valentino Simanjuntak Sebagai Komentator Olahraga Di Media Televisi” [Skripsi], Universitas Telkom, 2019.
[2]. I. S. Zahri, "Valentino Simanjuntak: Nafas Baru Komentator Bola Di Indonesia", Suarr.id, 14 Agustus 2018, [Website], Tersedia: http://suarr.id/valentino-simanjuntak-nafasbaru-komentator-bola-di-indonesia/ [Diakses: 4 November 2018]

[3]. F. D. Sitorus, "Sejarah Jebreeet dan Impian Valentino Simanjuntak", Bolasport, 18 September 2018, [Website]. Tersedia: https://www.bolasport.com/liga-1/306442sejarah-jebreeet-dan-impian-valentino simanjuntak?page $=1 \#$ [Diakses: 2 November 2018]

[4]. Sugiyono, Metode Penelitian Kombinasi (Mixed Metode), Bandung: Penerbit Alfabeta, 2016.

[5]. L. J. Moleong, Metodologi Penelitian Kualitatif Edisi Revisi, Bandung: PT Remaja Rosdakarya, 2012.

[6]. J. Rakhmat, METODE PENELITIAN KOMUNIKASI Dilengkapi contoh Analisis Statistik. Bandung: PT REMAJA ROSDAKARYA, 2009.

[7]. Ibrahim, Metodologi Penelitian Kualitatif, Bandung: Alfabeta, 2015.

[8]. H. K. Rampersad, AUTHENTIC PERSONAL BRANDING, Jakarta: PPM Publishing, 2008.

[9]. D. Haroen, Personal Branding: Sukses Karir di Era Milenial, Tangerang Selatan: DH Media, 2018.

[10].R. Sempana, "Analisis Perubahan Makna Pada Bahasa Yang Di Gunakan Oleh Komentator Sepakbola Piala Presiden 2017 Kajian Sematik" [Jurnal], Universitas PGRI Madiun, 2017.

[11].L. F. Bachman, Fundamental Considerations In Language Testing, England: Oxford University Press, 1990.

[12]. K. F. P. Siregar, "Analisis Ragam Bahasa Komentator Sepakbola Valentino Simanjuntak" [Skripsi], Universitas Muhammadiyah Sumatera Utara, 2018. 